\title{
Binuclear Ten-Membered Ring Cyclometallated Complexes of Digold(I) and their Reactions with Iodine and Bromine
}

Martin A. Bennett ${ }^{\mathrm{a}}$, Suresh K. Bhargava ${ }^{\mathrm{b}}$, David C. R. Hockless ${ }^{\mathrm{a}}$, Fabian Mohr ${ }^{\mathrm{b}, *}$, Kellie Watts ${ }^{\mathrm{a}}$, Lee L. Welling ${ }^{\mathrm{a}}$, and Anthony C. Willis ${ }^{\mathrm{a}}$

${ }^{a}$ Research School of Chemistry, Australian National University, Canberra, ACT 0200, Australia

b School of Applied Sciences, RMIT University, GPO Box 2476 V, Melbourne, Victoria 3001, Australia

* Present address: Departamento de Química Inorgánica, Instituto de Ciencia de Materiales de Aragón, Universidad de Zaragoza-C.S.I.C., 50009 Zaragoza, Spain

Reprint requests to Prof. Dr. M. A. Bennett. E-mail: bennett@ rsc.anu.edu.au

Z. Naturforsch. 59b, 1563 - 1569 (2004); received September 7, 2004

Unserem Freund und Kollegen Herrn Professor Dr. Hubert Schmidbaur in Anerkennung seiner schönen Arbeiten auf dem Gebiet der Goldchemie zum 70. Geburtstag gewidmet

The cyclometallated digold(I) complexes $\left[\mathrm{Au}_{2}\left(\mu-2-\mathrm{C}_{6} \mathrm{H}_{4} \mathrm{CH}_{2} \mathrm{PPh}_{2}\right)_{2}\right](\mathbf{1 0})$ and $\left[\mathrm{Au}_{2}\left(\mu-2-\mathrm{CH}_{2}\right.\right.$ $\left.\mathrm{C}_{6} \mathrm{H}_{4} \mathrm{PPh}_{2}\right)_{2}$ ] (11) have been synthesized by the reaction of $\mathrm{Li}\left[2-\mathrm{C}_{6} \mathrm{H}_{4} \mathrm{CH}_{2} \mathrm{PPh}_{2}\right]$ and $\mathrm{Li}\left[2-\mathrm{CH}_{2}\right.$ $\left.\mathrm{C}_{6} \mathrm{H}_{4} \mathrm{PPh}_{2}\right]$, respectively, with $\left[\mathrm{AuBr}\left(\mathrm{PEt}_{3}\right)\right]$. A single crystal X-ray structure analysis of $\mathbf{1 0}$ shows the linearly coordinated gold(I) atoms to be separated by 3.0035(9) $\AA$ in a puckered ten-membered ring. Both complexes add one mol equivalent of iodine to form initially gold(I)-gold(III) complexes $\left[\mathrm{Au}\left(\mu-2-\mathrm{C}_{6} \mathrm{H}_{4} \mathrm{CH}_{2} \mathrm{PPh}_{2}\right)_{2} \mathrm{AuI}_{2}\right](\mathbf{1 4 a})$ and $\left[\mathrm{Au}\left(\mu-2-\mathrm{CH}_{2} \mathrm{C}_{6} \mathrm{H}_{4} \mathrm{PPh}_{2}\right)_{2} \mathrm{AuI}_{2}\right]$ (17), which isomerize to the corresponding salts $\left[\mathrm{Au}\left(\kappa^{2}-P, C-\mathrm{C}_{6} \mathrm{H}_{4} \mathrm{CH}_{2} \mathrm{PPh}_{2}\right)_{2}\right]\left[\mathrm{AuI}_{2}\right](\mathbf{1 3 a})$ and $\left[\mathrm{Au}\left(\kappa^{2}-P, C-\mathrm{CH}_{2}\right.\right.$ $\left.\left.\mathrm{C}_{6} \mathrm{H}_{4} \mathrm{PPh}_{2}\right)_{2}\right]\left[\mathrm{AuI}_{2}\right]$ (16). In 13a the gold(III) cation is planar coordinated by a pair of chelate P-C donor ligands, the phosphorus and carbon atoms being, separately, mutually cis, as shown by X-ray structural analysis. From the reaction of $\mathbf{1 0}$ with 2 mol equivalents of bromine, the neutral chelate complex $\left[\mathrm{AuBr}_{2}\left(\kappa^{2}-P, C-\mathrm{C}_{6} \mathrm{H}_{4} \mathrm{CH}_{2} \mathrm{PPh}_{2}\right)\right](15)$ has been isolated and structurally characterized.

Key words: Gold(I), Cyclometallated Complexes, Phosphine Complexes 